\title{
APPLICATION OF ZEOLITES FOR IMMOBILIZATION OF GLUCOSE OXIDASE IN AMPEROMETRIC BIOSENSORS
}

\author{
Tatiana B. Goriushkina ${ }^{1,2}$, Burcu Akata Kurç3, \\ Albert Sacco Jr: ${ }^{4}$, Sergei V. Dzyadevych ${ }^{1,5}$ \\ ${ }^{1}$ Laboratory of Biomolecular Electronics, Institute of Molecular Biology and Genetics, National \\ Academy of Sciences of Ukraine, Zabolotnogo Street 150, 03143 Kyiv, Ukraine, tel/fax +380 4452643 97; \\ ${ }^{2}$ Biological Department, Taras Shevchenko Kyiv National University, \\ Volodymyrska Street 64, 01003 Kyiv, Ukraine; \\ ${ }^{3}$ Micro and Nanotechnology Department, Central Laboratory, \\ Middle East Technical University, 06530 Ankara, Turkey; \\ ${ }^{4}$ Center for Advanced Microgravity Materials Processing, Northeastern University, USA. \\ ${ }^{5}$ Institute of High Technologies, Taras Shevchenko Kyiv National University, \\ 64 Volodymyrska St., 01003, Kyiv, Ukraine \\ e-mail: tatiana_goryushkina@yahoo.com

\section{APPLICATION OF ZEOLITES FOR IMMOBILIZATION OF GLUCOSE OXIDASE IN AMPEROMETRIC BIOSENSORS} \\ Tatiana B. Goriushkina, Burcu Akata Kurç, Albert Sacco Jr., Sergei V. Dzyadevych

\begin{abstract}
An investigation was performed to evaluate the effect of different zeolites (silicalite, zeolite $\mathrm{Y}$ and zeolite Beta with varying $\mathrm{Si} / \mathrm{Al}$ ratio) on the performance of glucose amperometric biosensor based on immobilized glucose oxidase (GOD). It was observed that detection limit of biosensors based on GOD without zeolite was $0.64 \mathrm{mM}$ of glucose. However, in the case of GOD immobilization with zeolites $\mathrm{NH}_{4}$-Beta-25, Na-Beta and silicalites, biosensors with smaller detection limits within the range of 0.01 to $0.04 \mathrm{mM}$ of glucose were obtained. The study of selectivity of designed biosensors showed that biosensor based on GOD immobilized with zeolite $\mathrm{NH}_{4}$-Beta-25 was much selective comparing with biosensor based on GOD without zeolites. Stability of developed devises also was investigated, and in the case of biosensor with GOD and Silicalite-1 it was higher than for GOD without zeolite. Thus zeolites of different types can be effectively used for GOD immobilization in glucose amperometric biosensors development for optimization of sensitivity, selectivity and stability of these devises.
\end{abstract}

Keywords: amperometric biosensor, glucose oxidase, zeolites, glucose

\section{ЗАСТОСУВАННЯ ЦЕОЛІТІВ ДЛЯ ІММОБІЛІЗАЦІЇ ГЛЮКОЗООКСИДАЗИ ПРИ РОЗРОБЦІ АМПЕРОМЕТРИЧНИХ БІОСЕНСОРІВ}

\section{Т. Б. Горюшкіна, Аката Кури Б., А. Сакко, С. В. Дзядевич}

Анотація. Метою дослідження була оцінка впливу різних типів цеолітів (силікалітів, цеоліту Ү та цеолітів Бета з різним співвідношенням силіцій-алюміній) на робочі характеристики глюкозного амперометричного біосенсора на основі іммобілізованої глюкозооксидази (ГОД). Було встановлено, що границя визначення субстрату для біосенсора з ГОД без цеолітів становить 0,64 мМ глюкози, тоді як при іммобілізації ГОД з цеолітами $\mathrm{NH}_{4}$-Бета-25, Na-Бета та силікалітами були отримані біосенсори з меншею границею визначення - від 0,01 до 0,04 мМ. Дослідження селективності створених біосенсорів показало, що сенсор на основі ГОД, іммобілізованої з цеолітом $\mathrm{NH}_{4}$-Бета-25, був значно селективнішим у порівнянні з сенсором на основі ГОД без цеолітів. Також було проаналізовано стабільність розроблених біосенсорів та показано, що вона була вищою для ГОД, іммобілізованої з 
Силікалітом-1, ніж для ГОД без цеолітів. Тобто цеоліти різних типів можуть бути ефективно використані для іммобілізації ГОД при розробці глюкозних амперометричних біосенсорів для оптимізації чутливості, селективності та стабільності цих приладів.

Ключові слова: амперометричний біосенсор, глюкозооксидаза, цеоліти, глюкоза.

\section{ПРИМЕНЕНИЕ ЦЕОЛИТОВ ДЛЯ ИММОБИЛИЗАЦИИ ГЛЮКОЗООКСИДАЗЫ ПРИ РАЗРАБОТКЕ АМПЕРОМЕТРИЧЕСКИХ БИОСЕНСОРОВ}

\section{Т. Б. Горюшкина, Б. Аката Кури, А. Сакко, С.В. Дзядевич}

Аннотация. Целью исследования была оценка влияния разных типов цеолитов (силикалитов, цеолита Ү и цеолитов Бета с разным соотношением кремний-алюминий) на рабочие характеристики глюкозного амперометрического биосенсора на основе иммобилизированной глюкозооксидазы (ГОД). Было установлено, что граница определения субстрата для биосенсора с ГОД без цеолитов составляет 0,64 мМ глюкозы, тогда как при иммобилизации ГОД с цеолитами $\mathrm{NH}_{4}$-Бета-25, $\mathrm{Na}$-Бета и силикалитами были получены биосенсоры с меншею границей определения - от 0,01 до 0,04 мМ. Исследование селективности созданных биосенсоров показало, что сенсор на основе ГОД, иммобилизированной с цеолитом $\mathrm{NH}_{4}-$ Бета-25, был значительно более селективным в сравнении с сенсором на основе ГОД без цеолитов. Также была проанализирована стабильность разработанных биосенсоров и показано, что она была более высокой для ГОД, иммобилизированной с Силикалитом-1, чем для ГОД без цеолитов. Таким образом цеолиты разных типов могут быть эффективно использованы для иммобилизации ГОД при разработке глюкозных амперометрических биосенсоров для оптимизации чувствительности, селективности и стабильности этих приборов.

Ключевые слова: амперометрический биосенсор, глюкозооксидаза, цеолиты, глюкоза

\section{Introduction}

Zeolites are hydrated aluminosilicates belonging to the family of the tectosilicates, organized into regular three-dimensional networks with interconnected channels and cages [1, 2]. Since the 1990s, the combination of some of the attractive properties of zeolites with electrochemical methods of analysis has opened a new area of research in the analytical biochemistry. Nowadays zeolites are still of great interest due to their high surface areas, rigid and well defined pore structures, thermal stabilities, and tailorable surface charges with respect to other types of nanomaterials.

Particularly nano-sized pores of zeolites can be adjusted to precisely determined uniform openings allowing for molecules smaller than its pore diameter to be adsorbed. The different pore sizes of synthetic zeolites open up a wide range of possibilities in terms of sieving molecules of different size or shape from gases and liquids [3, 4]. On the other hand, in zeolite structures, $\mathrm{Si}$ atoms can be substituted with $\mathrm{Al}$ atoms, resulting in a negatively charged structure. These negative sites are balanced by counterions, usually alkaline and alkalineearth cations, which can be substituted by other cations, thus, providing zeolites with the property of ion exchange [1]. Such ion exchange properties of zeolites make them inevitable candidates for preparing ion-selective membranes for potentiometric cation sensing [5]. Zeolites offer selectivity based on the size, shape, and charge of the reactants [3]. Another advantage of zeolites is that their basic/acidic nature can be modified by varying the $\mathrm{Si} / \mathrm{Al}$ ratio with higher ratios indicating higher hydrophobicity and lower ion-exchange properties. Furthermore, zeolite acidity can be modified by exchanging extra-framework metal cations with $\mathrm{H}^{+}$[4]. The hydrophilic character of zeolites also makes them very suitable materials for the co-immobilization of enzymes and mediators in the preparation of biosensors [1]. The number and type of surface hydroxyl groups, which are important for immobilization applications, can be simply controlled by applying different heat treatment procedures [6]. Finally, zeolites are known to be stable both in wet and dry conditions and well-tolerated by microorganisms, leading to an enhanced compatibility with biochemical analyses [4]. All of these properties make zeolites unique nanomaterials and promising can- 
didates for the immobilization of biological molecules and for advanced analytical tasks.

It is well known that the immobilization of enzymes on solid surfaces plays a key role in the development of biosensors and has aroused increasing interest among researchers. Special additives placed into the sensitive membrane during immobilization can improve sensitivity and stability of immobilized enzyme and working characteristics of developed biosensor [7]. Recently, there has been an attention to the immobilization of proteins on nanoparticles which can retain the bioactivity of proteins to a large extent [4].

Promising results were also obtained upon using zeolites in biosensor applications, since it was shown that zeolites result in increased biosensor sensitivity and selectivity [1, 2, 8]. It was also shown that zeolites may establish a foundation for fabricating new type of biosensors without using mediators, because they can be used as an effective mediator to improve the stability and the analytical performances of biosensor [2,9]. Different types of zeolites have been studied to investigate different enzyme activities in biosensors [1, 2, 8-10]; however there is still great interest to optimize zeolite type, membrane preparation technique, biosensor selectivity and stability upon using zeolites in comparison with the already available procedures.

Accordingly, the objective of the current study is to investigate the effect of different zeolites, i.e., silicalite, zeolite $\mathrm{Y}$ and zeolite Beta with varying $\mathrm{Si} / \mathrm{Al}$ ratio, on the performance of immobilized glucose oxidase (GOD) for the first time. Furthermore, the advantages and disadvantages of using zeolites for the development of glucose amperometric biosensors in comparison with classical glucose biosensors without zeolites were explored.

\section{Materials and methods}

\section{Zeolites, enzymes and chemicals}

The zeolite types investigated in the present study include two silicalite samples with two different particle sizes (Silicalite- 1 is around $800 \mathrm{~nm}$ and Silicalite-2 is around 350-400 nm); commercial samples of zeolite $\mathrm{NH}_{4}$-Beta-25 (Si/Al ratio of 12.5), H-Beta-150 ( $\mathrm{Si} / \mathrm{Al}$ ratio of 75$)$ and $\mathrm{H}-\mathrm{Beta}-300(\mathrm{Si} / \mathrm{Al}$ ratio of 150); as-synthesized Na-Beta with Si/Al ratio of 12. The morphology of particles of investigated silicalites is shown in Fig. 1. Glucose oxidase (GOD) from Penicillium vitale with specific activity $130 \mathrm{U} / \mathrm{mg}$ was obtained from "Diagnostikum" (Lviv, Ukraine).
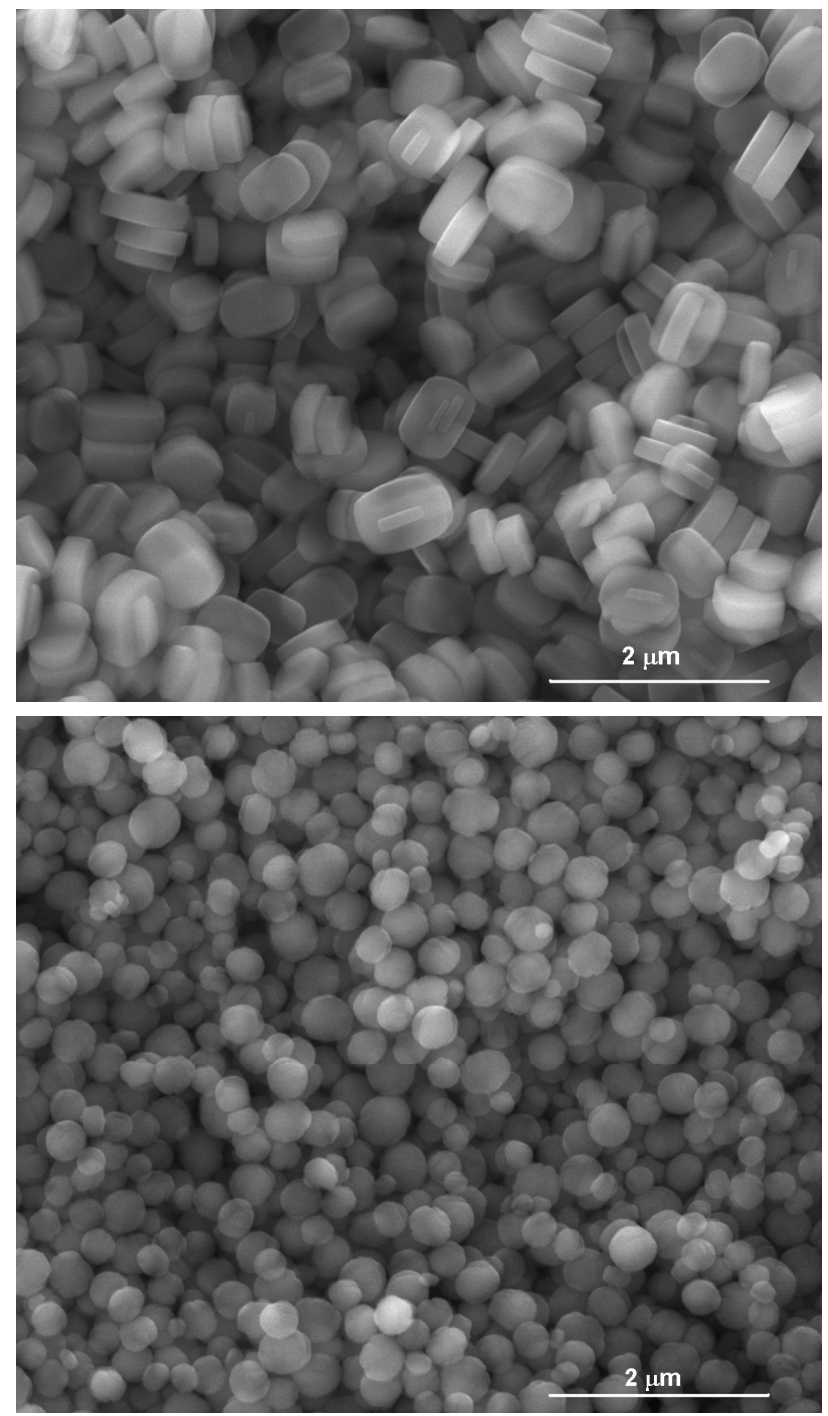

Fig. 1. Microphotography: Silicalite-1 (a), Silicalite-2 (b)

For electrochemical polymerization of the enzyme the monomer 3,4-ethylenedioxythiophene (EDT) from "Baytron M" (Germany) and 50\% polyethylene glycol from "Sigma" (Germany) were used. Glutaraldehyde produced by "Fluka" (UK) was also used as a polymer matrix for enzyme deposition. In addition the following chemicals were used: hydrogen peroxide from "Merck" (Germany), glucose from "Sigma" (USA), bovine serum albumin (BSA) from "Sigma" (USA), ethanol from "Sigma" (USA), $\mathrm{Na}_{2} \mathrm{HPO}_{4} \cdot 7 \mathrm{H}_{2} \mathrm{O}$ and $\mathrm{KH}_{2} \mathrm{PO}_{4}$ from "JT Baker" (Holland). All chemicals were of analytical reagent grade and used as received without additional purification.

\section{Amperometric experiments}

The key enzymatic reaction used for glucose determination by amperometric biosensor based on immobilized glucose oxidase is: 


\section{GOD \\ Glucose $+\mathrm{O}_{2} \longrightarrow$ Gluconolactone $+\mathrm{H}_{2} \mathrm{O}_{2}$;}

Substrate enzymatic transformation results in generating electrochemically active substance, hydrogen peroxide, decomposition of which causes formation of electrons measurable by means of amperometric transducer:

$$
\mathrm{H}_{2} \mathrm{O}_{2} \rightarrow \mathrm{O}_{2}+2 \mathrm{H}^{+}+2 \mathrm{e}^{-} \text {. }
$$

All electrochemical experiments were performed using the traditional three-electrode system in which the printed electrode SensLab (SensLab $\mathrm{GmbH}$, Leipzig, Germany) combines in itself all three electrodes - platinum working, auxiliary and reference [11]. Amperometric measurements at a constant potential were carried out in $5 \mathrm{ml}$ electrochemical cell using potentiostate PalmSens (Palm Instruments BV, the Netherlands).

\section{Enzyme immobilization by electrochemical} polymerization in the polymer poly (3,4-ethylenedioxythiophene)

Electropolymerisation of small monomers is a technique for the formation of a membrane at the electrode surface. This method allows one to select and maintain dimensions, shape and thickness of the matrix and to provide exact control over precipitation. Electropolymerised films can be successfully used in biosensors since these films, due to their permselectivity to hydrogen peroxide over other compounds, act as a selective barrier reducing the interfering effect of electroactive substances. More detailed characteristic of poly $(3,4-$ ethylenedioxythiophene) (PEDT) electrochemical polymerization was published previously [11].

For electrochemical polymerization, a mixture of components consisting of $10 \mathrm{mM}$ 3,4-ethylenedioxythiophene (EDT), 50\% polyethylene glycol (PEG) and $30 \%$ enzyme solution, was prepared in $20 \mathrm{mM}$ phosphate buffer, $\mathrm{pH}$ 6.2 for EDT and PEG solution and $\mathrm{pH} 7.2$ for GOD solution. PEDT was polymerized by application of the potential from +0.2 to +1.5 $\mathrm{V}$ at the rate of $0.1 \mathrm{~V} / \mathrm{s}$ during 15 cycles using the potentiostate PalmSens. The PEDT electrochemical synthesis was monitored by cyclic voltammetry. After the enzyme immobilization in PEDT the surface of SensLab electrode was washed with distilled water.

\section{Enzyme immobilization in glutaraldehyde vapour}

Glutaraldehyde is a polyfunctional agent which forms covalent bonds between biocatalytic particles or proteins. Therefore, enzyme immobilization with glutaraldehyde is often used for development of enzyme biosensors. This immobilization method produces a three-dimensional matrix, in which the enzyme is closely trapped with the electrode material, thus improving both retention of the biomolecule on the electrode surface and electrical communication [12]. For formation of the glutaraldehyde-based bioselective membrane, a drop of $30 \%$ GOD solution with 5\% BSA was put on the surface of working electrode. Then these sensors were placed into glutaraldehyde vapour atmosphere for $10 \mathrm{~min}$ and then dried in air.

\section{Experiments with zeolites}

In the case of electrochemical polymerization, a zeolite solution was added to the PEDT solution (only for Silicalite-1) or into the PEG solution (for all other zeolites). Final zeolite concentration in membrane in all cases was $5 \%$ by weight.

Cyclic voltammograms obtained at the SensLab electrode during electrochemical polymerization of EDT with GOD and zeolite are shown in Fig. 2. It was observed that the current decreased during every cycle, which illustrates the process of EDT polymerization and its deposition at the electrode surface.

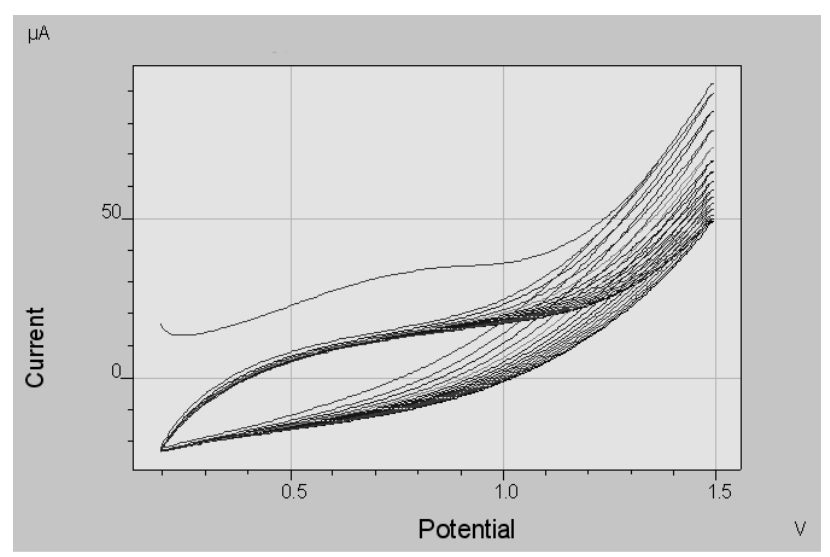

Fig. 2. Cyclic voltammograms obtained for platinum printed electrode SensLab during electrochemical polymerization of EDT with GOD and Silicalite-1

In the case of enzyme immobilization in glutaraldehyde vapor, the zeolite solution was prepared and added to the BSA solution. Once again, the zeolite concentration in the membrane was $5 \%$.

Glucose determination by amperometric biosensor and biosensors storage

All measurements were performed in $20 \mathrm{mM}$ $\mathrm{K}$, Na-phosphate buffer solution, $\mathrm{pH}$ 7.2, at room temperature in an open container with constant 
stirring. The glucose concentrations were changed in a controlled manner by adding aliquots of concentrated glucose solutions. After each measurement, the biosensor was washed with buffer solution to stabilize the base signal. The stability of the developed biosensors was tested using dry storage of the sensor at $+4{ }^{\circ} \mathrm{C}$ between the measurements.

\section{Results and discussion}

Two different methodologies for immobilization of glucose oxidase (GOD) with zeolites were investigated. These are electrochemical polymerization in the polymer poly(3,4-ethylenedioxythiophene) (PEDT) and immobilization in BSA-containing membrane in glutaraldehyde (GA) vapour. The results obtained using immobilization of GOD in GA and PEDT with zeolites can be seen in Fig. 3 .

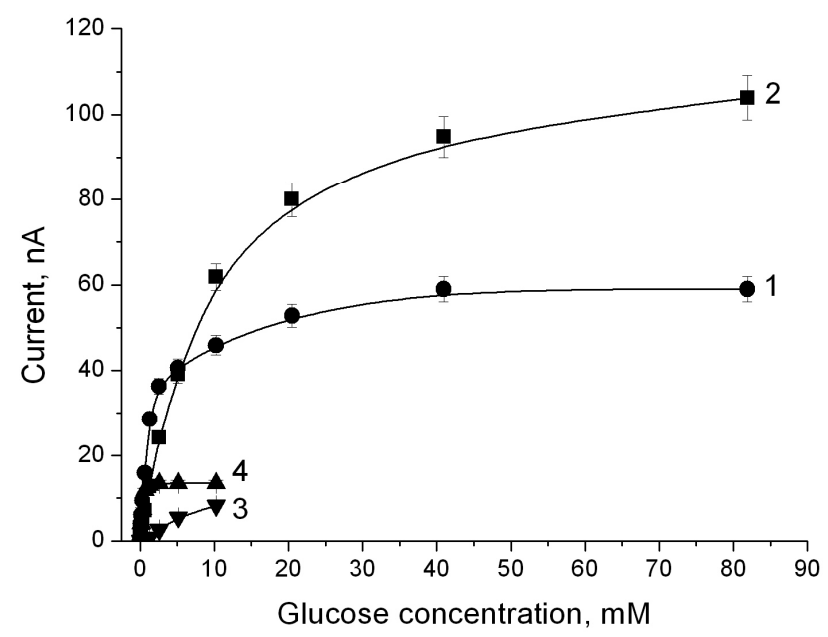

Fig. 3. Calibration curves of amperometric biosensors based on platinum printed SensLab electrode with GOD with Silicalite-1 immobilized in PEDT (1) and in GA (3) and GOD with Silicalite-2 immobilized in PEDT (2) and in GA (4). Measuring conditions: $20 \mathrm{mM}$ phosphate buffer, $\mathrm{pH} 7.2$, at potential of $+200 \mathrm{mV}$ versus intrinsic reference electrode

According to Fig. 3, immobilization of GOD using the electrochemical polymerization methodology in PEDT leads to biosensors with a wider dynamic range of work and higher level of signal. Thus, PEDT polymerization was chosen for the preparation of zeolite membranes on the electrodes and immobilization of enzymes for the rest of the studies. Accordingly, laboratory prototypes of glucose amperometric biosensors based on platinum printed electrodes SensLab and GOD immobilized in the PEDT with different zeolites and without zeolite were created. In all cases, including with $5 \%$ zeolite solution, it was observed that GOD was active after immobilization. The values of the response time, and time for stable background current achievement for all biosensors based on GOD with zeolites and GOD without zeolite were similar. However, biosensors based on zeolites H-Beta 150 and H-Beta 300 demonstrated very low response to the substrate.

The calibration curves of the laboratory prototypes of amperometric biosensors based on GOD without zeolite and GOD with various zeolites are shown in Fig. 4. Analysis of the working characteristics of developed biosensors demonstrated linear response to glucose using GOD immobilized in PEDT with zeolites H-Beta-150 and H-Beta-300 in almost the same concentration range as GOD immobilized in PEDT without zeolite. The detection limit for these biosensors was $0.32-0.64 \mathrm{mM}$ of glucose. However, in the case of GOD immobilization with the other zeolites investigated, biosensors with smaller detection limits within the range of 0.01 to $0.04 \mathrm{mM}$ of glucose were obtained.

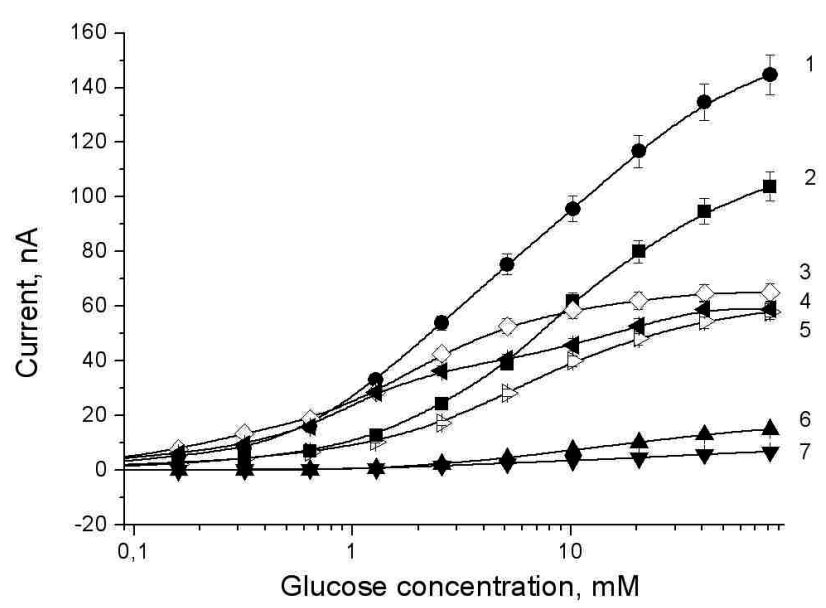

Fig. 4. Calibration curves of glucose amperometric biosensors based on GOD without zeolite (4) and GOD with zeolites Silicalite-1 (1), Silicalite-2 (2), $\mathrm{NH}_{4}-\mathrm{Be}-$ ta-25 (3), Na-Beta (5), H-Beta-300 (6), H-Beta-150 (7), immobilized in PEDT. Measuring conditions: 20 $\mathrm{mM}$ phosphate buffer, $\mathrm{pH} 7.2$, at a potential of $+200 \mathrm{mV}$ versus intrinsic reference electrode

It is well-known that the selectivity of biosensors is important parameter to determine prior to application of these devices in analysis of real samples. Thus responses of the developed glucose biosensors to ethanol, which is one of the main interfering substances, were studied. The current observed at different ethanol concentrations for different zeolite biosensors are shown in Fig. 5. As can be seen, the responses to ethanol of the biosensors based on GOD without zeolite and GOD immobilized with 
both of the silicalite samples are almost the same. Sensors based on zeolites H-Beta-300, 150 and NaBeta demonstrate lower responses to ethanol, but their signals to glucose are not high (Fig. 4). The optimum combination of high glucose signal and a minimum ethanol signal (selectivity) were observed for GOD immobilized with $\mathrm{NH}_{4}$-Beta-25. It can be hypothesized that the $\mathrm{Al}$ content is important to achieve high selectivity in the current biosensor, since almost no change of selectivity was observed using silicalite samples. Selectivity is an important parameter to consider in biosensors especially for real samples [12]. Thus, silicalites are not promising candidates for this particular purpose.

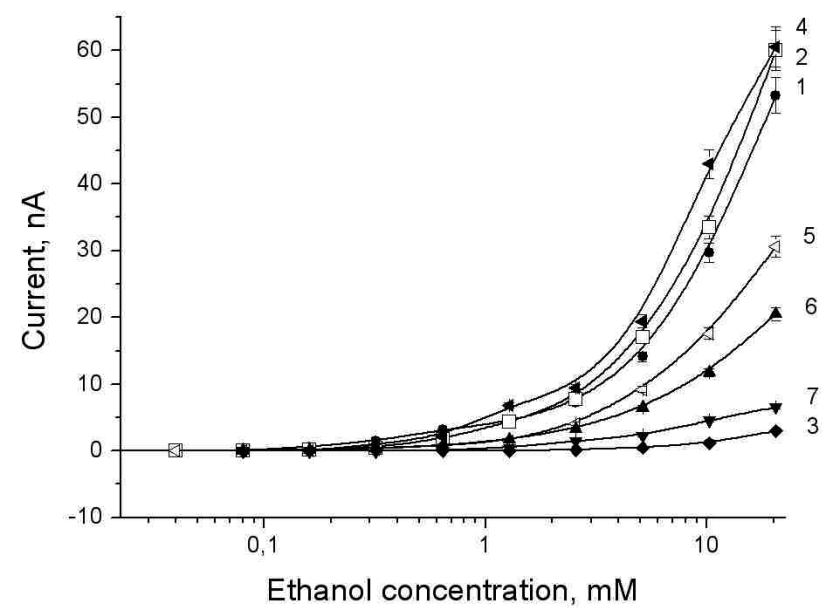

Fig. 5. Responses of glucose amperometric biosensors to ethanol based on GOD without zeolite (4) and GOD with zeolites Silicalite-1(1), Silicalite-2 (2), $\mathrm{NH}_{4}$ Beta-25 (3), Na-Beta (5), H-Beta-300 (6), H-Beta-150 (7), immobilized in PEDT. Measuring conditions: 20 $\mathrm{mM}$ phosphate buffer, $\mathrm{pH} 7.2$, at a potential of $+200 \mathrm{mV}$ versus intrinsic reference electrode

Also, the storage stability of all the biosensors was investigated (Fig. 6). GOD immobilized in PEDT without zeolite was not highly stable. It was observed that only $70 \%$ of initial response was observed after the first week and that dropped to approximately $38 \%$ by the second week of storage. Activity of biosensors based on GOD immobilized with zeolites Silicalite- 2 and H-Beta- 150 rapidly decreased during first $4-5$ days after immobilization (from $110 \%$ to $\sim 23 \%$ ). GOD immobilized with $\mathrm{NH}_{4}$-Beta 25 demonstrated better stability: $64 \%$ of initial response in 5 days of storage. For biosensors with H-Beta-300 and Silicalite-1, storage stability was much higher for the first 5 days. These devises demonstrated around $100 \%$ and $75 \%$ of the initial signal respectively during the first week after immobilization. With these zeolite samples, higher reproducibility was obtained as well with respect to the rest of the zeolite samples. These results suggest that low Al content maybe important to achieve high stability. Also, the particle size of Silicalite-1 crystals is about twice as much of the Silicalite-2 crystals (Fig. 1a and b). Thus, particle size maybe important as well.
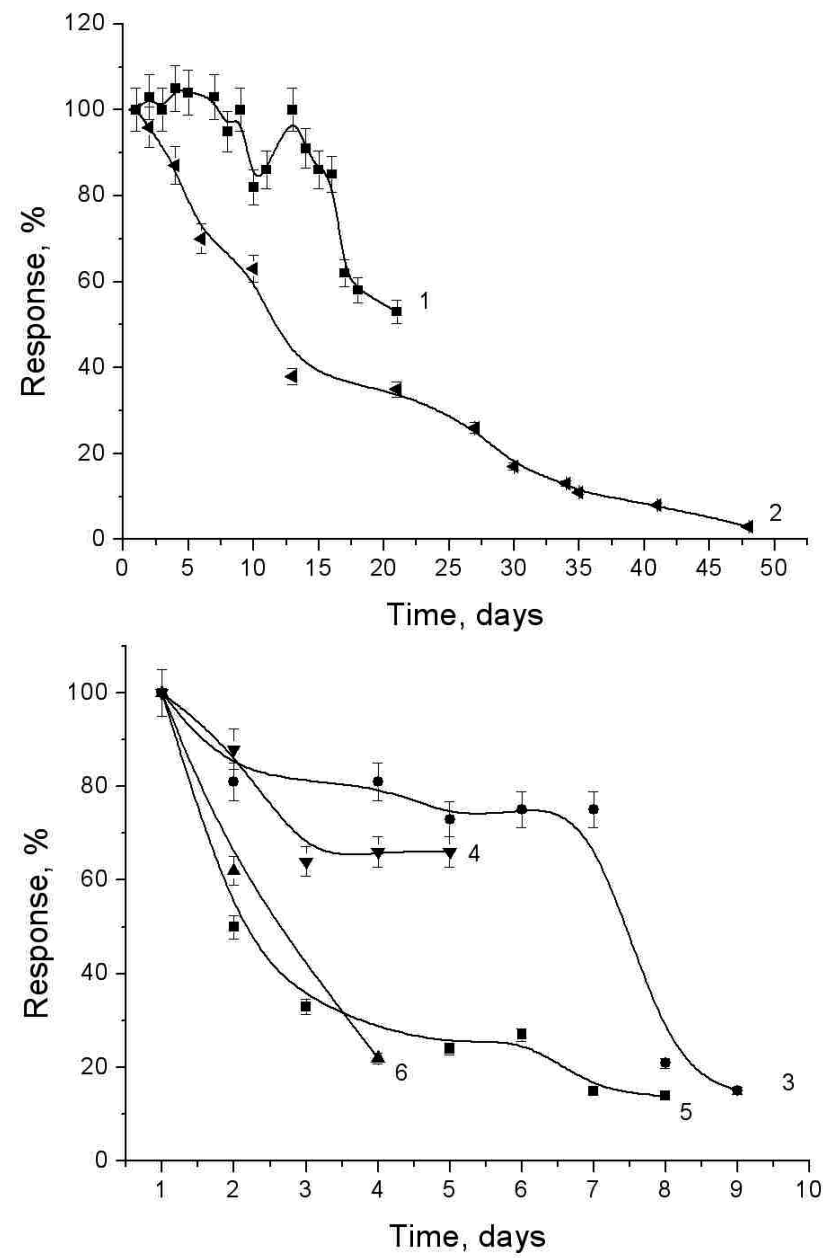

Fig. 6. Investigation of storage stability of glucose amperometric biosensors based on electrode SensLab and GOD without zeolite (a, 2), and GOD with zeolite Silicalite-1 (a, 1), H-Beta-300 (b, 3), NH-Beta-25 (b, 4), Silicalite-2 (b, 5), H-Beta $150(\mathrm{~b}, 6)$. Measuring conditions: $20 \mathrm{mM}$ phosphate buffer, $\mathrm{pH} \mathrm{7.2,} \mathrm{at} \mathrm{potential} \mathrm{of}$ $+200 \mathrm{mV}$ versus intrinsic reference electrode

Results of comparative analysis of glucose amperometric biosensors based on GOD immobilized in the PEDT without zeolite and with different zeolites are shown in Table 1. As can be seen, biosensor with GOD and Silicalite-1 demonstrates the best working characteristics: low detection limit, high level of response, high storage and operational stability and sufficient selectivity. Biosensors with $\mathrm{NH}_{4}$-Beta-25 and Na-Beta also have their advantages: low detection limit for both biosensors and very high selectivity to the substrate for $\mathrm{NH}_{4}$-Beta- 25 based biosensor. 
Table 1 Results of comparative analysis of glucose amperometric biosensors based on GOD without zeolite and GOD with different zeolites

\begin{tabular}{|c|c|c|c|c|}
\hline Zeolite & $\begin{array}{c}\text { Dynamic range, } \\
\text { mM glucose }\end{array}$ & $\begin{array}{c}\text { Response } \\
\text { at saturation, nA }\end{array}$ & $\begin{array}{c}\text { Response to 20 mM ethanol, } \\
\% \text { of 20 mM glucose response }\end{array}$ & Storage stability \\
\hline Without zeolite & $0.64-20$ & 34 & 39 & $\begin{array}{c}62 \% \text { after 10 days, } \\
35 \% \text { after 20 days }\end{array}$ \\
\hline Silicalite-1 & $0.02-5$ & 75 & 29 & $\begin{array}{c}100 \% \text { after 8 days } \\
83 \% \text { after 16 days }\end{array}$ \\
\hline Silicalite-2 & $0.04-10$ & 62 & 75 & $14 \%$ after 8 days \\
\hline H-Beta-300 & $0.64-10$ & 7 & 200 & $77 \%$ after 7 days \\
\hline H-Beta-150 & $0.32-10$ & 3.5 & 146 & $23 \%$ after 4 days \\
\hline NH $_{4}$-Beta-25 & $0.02-5$ & 53 & 5 & $64 \%$ after 5 days \\
\hline Na-Beta & $0.01-10$ & 40 & 63 & $50 \%$ after 2 days \\
\hline
\end{tabular}

Taken together these results suggest that zeolites of different types can be used as alternatives for GOD immobilization in amperometric biosensors development. It was shown that different zeolites with different characteristics lead to different biosensor results. Thus, it can be hypothesized that different properties of zeolites, such as their ion exchange behaviors, particle sizes, surface groups, pore sizes, and $\mathrm{Si} / \mathrm{Al}$ ratios may be tailored in such a way that the optimum performance from a biosensor can be achieved upon choosing the right zeolite type and tuning its characteristic properties. Accordingly, future research will focus on evaluating such zeolite characteristics for potential development of the optimum electrodes for a desired purpose.

This study was partly supported by Scientific and Technical Research Council of Turkey (TUBITAK) with the project number 180M576, and partly by a European Union project with the project number PIRSES-GA-2008-230802.

\section{References}

1. Granda Valdes M., Perez-Cordoves A.I., Diaz-Garcia M.E. Zeolites and zeolite-based materials in analytical chemistry // Trends in Analytical Chemistry. - 2006. - Vol. 25, No. 1. - P. $24-30$.

2. Хie Y., Liu H., Hu N. Layer-by-layer films of hemoglobin or myoglobin assembled with zeolite particles: Electrochemistry and electrocatalysis // Bioelectrochemistry. - 2007. - Vol. 70. - P. 311-319.

3. Mazloum Ardakani M., Akrami Z., Kazemian H., Zare H.R. Electrocatalytic characteristics of uric acid oxidation at graphite-zeolite-modified electrode doped with iron (III) // Journal of Electroanalytical Chemistry. - 2006. - Vol. 586. - P. 31-38.
4. Tavolaro A., Tavolaro P., Drioli E. Zeolite inorganic supports for BSA immobilization: Comparative study of several zeolite crystals and composite membranes // Colloids and Surfaces B: Biointerfaces. - 2007. Vol. 55. - P. 67-76.

5. Arvand-Barmchi M., Mousavi M.F., Zanjanchi M.A., Shamsipur M. A PTEV-based zeolite membrane potentiometric sensor for cesium ion // Sensors and Actuators B. - 2003. - Vol. 96. - P. 560-564.

6. Öztürk S., Akata B. Oriented assembly and nanofabrication of zeolite A monolayers // Microporous and Mesoporous Materials. - 2009. - Vol. 126. - 228-233.

7. Vidinha P., Augusto V., Nunes J., Lima J.C., Cabral J.M.S., Barreiros S. Probing the microenvironment of sol-gel entrapped cutinase: The role of added zeolite NaY // Journal of Biotechnology. - 2008. Vol. 135. - P. 181-189.

8. Zhou J., Li P., Zhang S., Long Y., Zhou F., Huang Y., Yang P., Bao M. Zeolite-modified microcantilever gas sensor for indoor air quality control // Sensors and Actuators B. - 2003. - Vol. 94. - P. 337-342.

9. Serban S., El Murr N. Synergetic effect for NADH oxidation of ferrocene and zeolite in modified carbon paste electrodes. New approach for dehydrogenase based biosensors // Biosensors and Bioelectronics. 2004. - Vol. 20. - P. 161-166.

10. F. Manea, A. Pop, C. Radovan, P. Malchev, A. Bebeselea, G. Burtica, S. Picken, J. Schoonman Voltammetric Detection of Urea on an Ag-Modified ZeoliteExpanded Graphite-Epoxy Composite Electrode // Sensors. - 2008. - Vol. 8. - P. 5806-5819.

11. Goriushkina T., Shkotova L., Gayda G., Klepach H., Gonchar M., Soldatkin A., Dzyadevych S. Amperometric biosensor based on glycerol oxidase for glycerol determination // Sens. Actuators B: Chemical. 2009, doi:10.1016/j.snb.2008.11.051.

12. Goriushkina T., Soldatkin A., Dzyadevych S. Application of Amperometric Biosensors for Analysis of Ethanol, Glucose, and Lactate in Wine // J. Agric. Food Chem. - 2009, Vol. 57, №15. - P. 6528-6535. 